\title{
EDITORIAL
}

\section{O Congresso Brasileiro de Geologia está às portas}

$\mathrm{Na}$ Assembleia Geral da Sociedade Brasileira de Geologia, ocorrida em 2012, durante o último Congresso Brasileiro de Geologia realizado em Santos (SP), foi aprovada a candidatura proposta pelo Núcleo Bahia-Sergipe para organizar o 470 CONGRESSO BRASILEIRO DE GEOLOGIA (47 CBG), em 2014, na cidade de Salvador (BA).

O 470 CBG (http://www.47cbg.com.br) será realizado no período de 21 a 26 de setembro de 2014, no Centro de Convenções da Bahia. O CBG é o evento mais tradicional e abrangente das Geociências no Brasil e, devido ao nível e repercussão das discussões técnico-cientificas e ao número de participantes, tem ampliado a sua repercussão internacional.

O tema "Trilhando as Novas Fronteiras dos Recursos Naturais" do 47 CBG materializa uma das respostas dadas pela comunidade geológica brasileira ante aos desafios e as demandas do setor produtivo, da comunidade técnico-científica e da sociedade.

O principal objetivo do $47^{\circ} \mathrm{CBG}$ é congregar a comunidade geológica e áreas afins para difundir os conhecimentos atuais das Geociências, por meio da divulgação dos progressos e principais resultados da produção técnico-cientifica. Além disso, realizar discussão de temas políticos relevantes e geração de oportunidades de negócios envolvendo o setor mineral, petrolífero e ambiental. O 470 CBG constitui, portanto, uma excelente oportunidade para discutir a contribuição da Geologia no desenvolvimento da indústria mineral (metais, não metais, materiais de construção, dentre outros) e petrolífera e na gestão das grandes cidades, da hidrogeologia e das questóes turísticas e ambientais, contribuindo, efetivamente, para o desenvolvimento sustentado do nosso país. Os CBGs têm sido igualmente um fórum pertinente onde se têm discutido questôes nacionais relativas à formação graduada e pós-graduada.

O crescimento no número de participantes nas duas ediçôes anteriores do Congresso Brasileiro de Geologia (2010, 2012) foi de 36\%. Além dessa tendência natural de crescimento, o fato de o evento ser em Salvador tende sempre a ampliar o número de participantes pelas características turísticas agradáveis da cidade. Existe, portanto, a expectativa de se ter um público superior a 4 mil participantes no $47^{\circ} \mathrm{CBG}$. O perfil dos participantes desse evento é essencialmente constituído por profissionais de empresas, professores, pesquisadores, estudantes de graduação e pós-graduação.

O 47॰ CBG seguirá a estrutura formal adotada em eventos anteriores, com a realização de simpósios temáticos, sessões técnico-científicas, conferências, mesas-redondas, minicursos, excursôes, visitas técnicas, reunióes especiais e lançamentos de materiais didáticos e técnicos. Ampla programação cultural e social estará disponível, objetivando propiciar o bem-estar e oportunidades de lazer aos congressistas e acompanhantes durante suas estadias em Salvador. Vários fóruns especiais irão promover o debate de assuntos diretamente relacionados ao tema central do evento, assim como assuntos importantes demandados por sociedades científicas, empresas, instituiçóes, grupos de pesquisa, entre outros.

No mês de dezembro de 2013, iniciou-se o processo de submissão de trabalhos para o $47^{\circ} \mathrm{CBG}$, devendo terminar esse prazo no final de fevereiro de 2014 . As especificaçóes de como devem ser formatados os trabalhos para a submissão e sua posterior avaliação encontram-se apresentadas na home-page do evento.

As inscriçóes para o 470 CBG foram abertas em novembro de 2013, existindo desconto importante para os congressistas que fizerem o quanto antes as suas inscriçóes. Os associados da SBG, assim como os das sociedades afiliadas, têm igualmente descontos.

O $47^{\circ} \mathrm{CBG}$ reservou no Centro de Convençôes da Bahia excelente área para stands, na qual empresas, institutos de pesquisas, sociedades científicas e instituiçôes de ensino poderão divulgar suas açóes e imagens. O portfolio do $47^{\circ} \mathrm{CBG}$ apresenta várias oportunidades para a completa divulgação de empresas e instituiçôes, tanto durante a organização quanto na realização do evento. Os interessados podem entrar em contato com a Comissão Organizadora do $47^{\circ} \mathrm{CBG}$ por meio do site http://www.47cbg.com.br.

Espera-se contar com a presença do(a) colega em setembro de 2014 em Salvador, não somente para aproveitar as informaçôes técnico-científicas relevantes que irão ser apresentadas em nosso evento, mas também, como já disse Caetano Veloso na música "Bahia com H", foi nesse Estado alegre e festeiro que começou oficialmente o Brasil: "Salve! A santa Bahia imortal, Bahia de sonhos mil! Eu fico contente da vida em saber que a Bahia é Brasil".

Herbet Conceiçáo

Presidente do CBG

Simone Cerqueira Pereira Cruz

Vice-Presidente do $C B G$ 


\section{EDITORIAL}

\section{The Brazilian Geological Congress is coming}

In the General Assembly of the Brazilian Society of Geology, held in 2012 during the last Brazilian Geology Congress, carried out in Santos, São Paulo, the candidacy proposed by the team of Bahia-Sergipe was approved for the organization of the $37^{\text {th }}$ Brazilian Geology Congress ( $47^{\text {th }}$ BGC), in 2014, in Salvador, Bahia.

The 47 $7^{\text {th }}$ BGC (http://www.47cbg.com.br) will be held from 21 to 26 September, 2014, in the Convention Center of Bahia. BGC is the most traditional and comprehensive Geosciences event in Brazil, and due to the level and repercussion of its technical and scientific discussion, as well as the number of participants, its international repercussion has also been increasing.

The theme "Trilhando as Novas Fronteiras dos Recursos Naturais" (Going through the New Frontiers of Natural Resources), which will be the base of the $47^{\text {th }}$ BGC, materializes one of the answers given by the Brazilian geological community facing the challenges and the demands of the productive sector, the technical and scientific community and the society.

The main objective of the $47^{\text {th }} \mathrm{BGC}$ is to congregate the geological community and common areas to share current knowledge about Geosciences, by means of publicizing progresses and the main results of the technical and scientific production. Besides, it aims at discussing relevant political themes and at generating business opportunities involving the mineral, petroliferous and environmental fields. The $47^{\text {th }} \mathrm{BGC}$, therefore, is an excellent chance to discuss the contribution of Geology in the development of the mineral (metals, nonmetals, building materials, among others) and petroliferous industries, as well as the management of big cities, hydrogeology and touristic and environmental matters, thus effectively contributing for the sustained development of our country. CBGs have also been a pertinent forum to discuss national issues with regard to graduation and postgraduation.

The increasing number of participants in the previous editions of BGC $(2010,2012)$ was of $36 \%$. Besides this natural growing trend, the fact that this even will be held in Salvador tends to the increased number of participants, due to the pleasant tourist attractions of the city. Therefore, the expectation is of an audience of more than 4 thousand participants for the $47^{\text {th }}$ BGC. The profile of the participants of this event is essentially composed of professionals in companies, professors, researchers, graduate and postgraduate students.

The $47^{\text {th }}$ BGC will adopt the same formal structure from the previous events, with the performance of thematic symposiums, technical and scientific sessions, conferences, round tables, mini-courses, excursions, technical visits, special meetings and launching of didactic and technical materials. A broad cultural and social schedule will be available in order to provide well-being and leisure opportunities for the participants during their stay in Salvador. Several special forums will promote debates about subjects that are directly related to the central theme of the event, as well as important subjects requested by scientific societies, companies, institutions, research groups, among others.

In December, 2013, the process to submit studies for the $47^{\text {th }}$ BGC began, and this deadline will be concluded in the end of February, 2014. The format specifications for the studies to be submitted and their evaluation are presented in the homepage of the event. It has been possible to enroll to the $47^{\text {th }}$ BGC since November 2013 , and there is an important discount for participants who enroll early. SBG associates, as well as the ones from affiliated societies, also have discounts.

The $47^{\text {th }}$ BGC selected an excellent area for stands in the Convention Center of Bahia, in which companies, research institutes, scientific societies and teaching institutions will be able to publicize their actions and images. The portfolio of the $47^{\text {th }}$ BGC presents several opportunities for the complete publicizing of companies and institutions, both during the organization and at the conduction of the event. Those who are interested can get in touch with the Organization Committee of $47^{\text {th }}$ BGC through the website http://www. $47 \mathrm{cbg}$.com.br.

We hope to count on your presence in September 2014, in Salvador, not only to enjoy the relevant technical and scientific information that will be presented during our event, but also, quoting Caetano Veloso, in the song "Bahia com H", since it was in this happy and party state that Brazil was officially born: "Hail! Saint immortal Bahia, Bahia of a thousand dreams! I am very happy to know that Bahia is Brazil”.

Herbet Conceiçáo President of $B G C$

Simone Cerqueira Pereira Cruz Vice-President of $B G C$ 